\title{
Exposure as Collected Group Identifier
}

National Cancer Institute

\section{Source}

National Cancer Institute. Exposure as Collected Group Identifier. NCI Thesaurus. Code C117468.

A character or string that represents a collected exposure group. 